\title{
Life Cycle Assessment of Flooring Materials: Case Study
}

\author{
Å. JÖNSSON* \\ A-M. TILLMAN* \\ T. SVENSSON*
}

(Received 2 June 1995; accepted 26 September 1996)

\begin{abstract}
The environmental impact of the three flooring materials linoleum, vinyl flooring and solid wood flooring during their life cycles was assessed and compared through life cycle assessment (LCA). The scenarios used describe a Swedish situation. Only impacts on the natural environment were studied. The quantitative results of the inventory analysis were evaluated by using three different assessment methods. According to the results, solid wood flooring proved to be clearly the most environmentally sound flooring. Linoleum was ranked as more environmentally sound than vinyl flooring, although this was less evident in comparison with ranking the solid wood flooring. (C) 1997 Elsevier Science Ltd.
\end{abstract}

\section{INTRODUCTION}

THE consequences of the human impact on the environment have become increasingly clear in recent years. A number of previously unknown environmental problems have emerged at local, regional and global levels, in spite of considerable efforts to decrease environmental emissions from identified point sources. Consequently, demands are now being made on the environmental soundness of products. From industry there is a demand for methods of improving products from the environmental point of vicw, both for internal use and for marketing purposes. Authorities need methods which can be used to assess the environmental consequences of product related decisions. Life cycle assessment (LCA) is becoming an increasingly important method for making product related environmental assessments.

Until recently, the LCA method has primarily been applied to products with short lifetimes, such as packaging. When applying LCA to building materials and components, special methodological problems arise because of the relatively long lifetime and the complex purpose of these products. Therefore, a project entitled "Environmental $\Lambda$ ssessment of Buildings and Building Materials" has been initiated at the Department of Technical Environmental Planning of Chalmers University of Technology (CTH). The case study of flooring materials presented in this article constitutes the first step in this project. All results, background data and complete references have been published and can be found in [1]. Another LCA of flooring materials has been performed by Potting et al. [2], and some of the background data for the Swedish study have been taken from there.

* Technical Environmental Planning, Chalmers University of Technology, S-412 96 Gothenburg, Sweden.

\section{OBJECTIVE}

The environmental impact of three flooring materials during their life cycles was assessed and compared using the LCA method. The objective was to make a specific comparison between the environmental impacts of the life cycle of some flooring materials and to develop a methodology for LCA of building materials.

\section{METHODOLOGICAL FRAMEWORK}

The methodology of LCA generally consists of four steps [3] as follows.

\section{Goal definition and scoping}

This component consists of defining the purpose of the study and its scope, establishing the functional unit and establishing a procedure for quality assurance of the study.

\section{Inventory analysis}

In the inventory analysis, the systems studied and their system boundaries are defined and process flow charts are drawn. Once the system has been subdivided into its component sub-systems, the data are gathered. The data gathered comprise production, resource use, energy use, emissions to air and water, and waste generation.

\section{Impact assessment}

The impact assessment is a quantitative and/or qualitative process to characterise and assess the effects of the environmental burdens quantified in the inventory analysis. The process may be divided into three steps: classification, characterisation and valuation. The results should be presented in a manner that is consistent with the objective of the study. 


\section{Improvement assessment}

This is the component of an LCA in which options for reducing the environmental impacts or burdens of the system(s) under the study are identified and evaluated.

Methodology for the goal definition and scoping and inventory analysis is, according to SETAC (Society of Environmental Toxicolngy and Chemistry) [3], defined and understood. It is more difficult to draw up guidelines for how to translate environmental loads quantified in the inventory into measures of environmental effects, and how different types of effects are to be weighed against one another.

\section{GOAI. DEFINITION AND SCOPING}

The purpose of the study was to assess and compare the environmental impact from cradle to grave for floor coverings. The covering of one square metre of flooring during one year of operation was therefore chosen as the functional unit, or basis of comparison.

The flooring materials linoleum, vinyl flooring and untreated solid wood flooring were chosen to be studied. Linoleum and vinyl flooring are the most widely sold flooring materials in Sweden, and solid wood flooring is often referred to as the traditional and environmentally friendly alternative to modern flooring. It was of interest to ascertain whether or not this view is confirmed by quantitative LCA. The study was delimited in the following respects (the system boundaries are described in greater detail in [1]).

- Floorings for domestic use were studied.

- The scenarios describe a Swedish situation, and the data are applicable to the situation prevailing today.

- It was assumed for the calculations that there is no recycling or recovery of the flooring materials, and that all materials are incinerated, with energy recovery, after use.

- The three studied products all have a calorific value and could alternatively be used as fuels. Since the energy recovered from incineration was accounted for as an energy gain, the calorific value of the materials was treated as an energy cost.

- It was assumed that all pigments used consisted of titanium dioxide.

- The environmental impact of multi-output processes was allocated in proportion to the physical parameter most closely reflecting the economic value, which in most cases resulted in weight being used. No allocation was made between the two functions of incineration, waste elimination and heat production. Instead, the heat produced was reported as a useful energy flow leaving the systems analysed.

- The study was confined to effects on the natural environment (local indoor effects on human health were omitted).

- The methodology of LCA does not include the risks of accidents or parameters for which the environmental impact has not yet been thoroughly examined.

- Production of electricity was not included in the systems analysed, due to lack of data. Electricity use was thus accounted for only as the amount used. When interpreting the results, the amount of electricity used reflects a number of environmental impacts, including flooded land from hydropower, radioactive waste from nuclear power and emissions to the air from fossil fuel based electricity production.

- The environmental impact of cleaning and maintenance was omitted. It was roughly assumed that the cleaning habits are probably independent of what floor covering is used. In addition, no reliable data were available in this area.

- The impact of adhesives was assessed as being similar for linoleum and vinyl flooring, and was therefore omitted, although omitting this impact is unfavourable to the solid wood flooring, for which only a small amount of adhesives is used.

- Some additives in the products were used in such small quantities that their environmental impact was disregarded in the study.

- General data [4] were used to describe the environmental impact of energy use and transportation.

- The load-bearing function of the floors was not taken into account.

Table 1 presents some data and conditions for the product types that were chosen for the study. For linoleum and vinyl flooring, specific manufacturers were chosen as the main data sources. The linoleum studied was produced in the Netherlands, whereas the two other floorings were produced in Sweden.

\section{INVENTORY ANALYSIS}

A flow chart was drawn for each of the floorings (Figs 1-3) and then data on environmental load was gathered for processes and transports of the life cycles. In this study, the necessary information was gathered from producing companies, authorities and the literature, including other LCA studies. For some data, standard values were used. The results of the inventory analysis were calculated for each flooring's life cycle per square metre, as presented in Tables $2-4$.

\section{The life cycle of linoleum}

Linseed oil, which is the most important raw material in the actual linoleum paste, acts as a binder. The oil is catalytically oxidised and polymerised with air in large tanks. This produces linoxyn, a reddish-brown highly elastic mass. The linoxyn is then mixed with resin from coniferous trees, known as colophonium. The mixed linoxyn and resin form a cement, which is left to mature. The cement is then mixed with powdered cork, powdered wood, powdered limestone and pigment. Powdered wood and cork are used to give the sheeting resiliance, and powdered limestone is used as a mineral filler. In linoleum, titanium dioxide is used as the main pigment. After the mixing process, a homogeneous linoleum mass is obtained, which is then converted into granules. The granules are fused to backing, made from jute, under pressure and heat. The still soft sheeting is hung up in long loops in drying rooms to mature further, and is left there for two to three weeks. As the last stage of manufacture the sheets are coated with a thin layer of acrylate. After this has been done, the sheeting is trimmed and rolled, and after packaging it is ready for sale. The production chain takes four to six weeks. 
Table 1. Selected product data for linoleum, vinyl flooring and solid wood flooring

\begin{tabular}{lcccl}
\hline & $\begin{array}{c}\text { Market share [5] } \\
\text { (\% of Swedish flooring } \\
\text { market in 1992) }\end{array}$ & $\begin{array}{c}\text { Specific } \\
\text { weight } \\
\left(\mathrm{kg} / \mathrm{m}^{2}\right)\end{array}$ & $\begin{array}{c}\text { Assumed } \\
\text { lifetime } \\
\text { (years) }\end{array}$ & Main data sources \\
\hline $\begin{array}{l}\text { Linoleum } \\
\text { Vinyl flooring }\end{array}$ & 18 & 2.3 & 25 & $\begin{array}{l}\text { Forbo-Krommenie [6] } \\
\text { Hydro Plast AB [7] } \\
\text { Solid wood flooring }\end{array}$ \\
\hline
\end{tabular}

\section{The life cycle of vinyl flooring}

Polyvinyl chloride (PVC) is one of the main constituents of vinyl flooring. It is produced from sodium chloride $(\mathrm{NaCl})$, ethylene and electric power. Ethylene originates from crude oil. The production of PVC is divided into three sub-processes: the production of chlorine, the production of vinyl chloride monomer (VCM) and the production of PVC. First, sodium chloride is elec- trolysed to sodium hydroxide $(\mathrm{NaOH})$, chlorine $\left(\mathrm{Cl}_{2}\right)$ and hydrogen $\left(\mathrm{H}_{2}\right)$. In the VCM factory, chlorine and ethylene are reacted to ethylene dichloride (EDC). VCM is then made from EDC. In the PVC factory, VCM is polymerised to PVC under high pressure. After polymerisation and drying, the PVC undergoes further processing. In the manufacturing of flooring, PVC granules are mixed with additives (plasticisers, pigments, fillers,

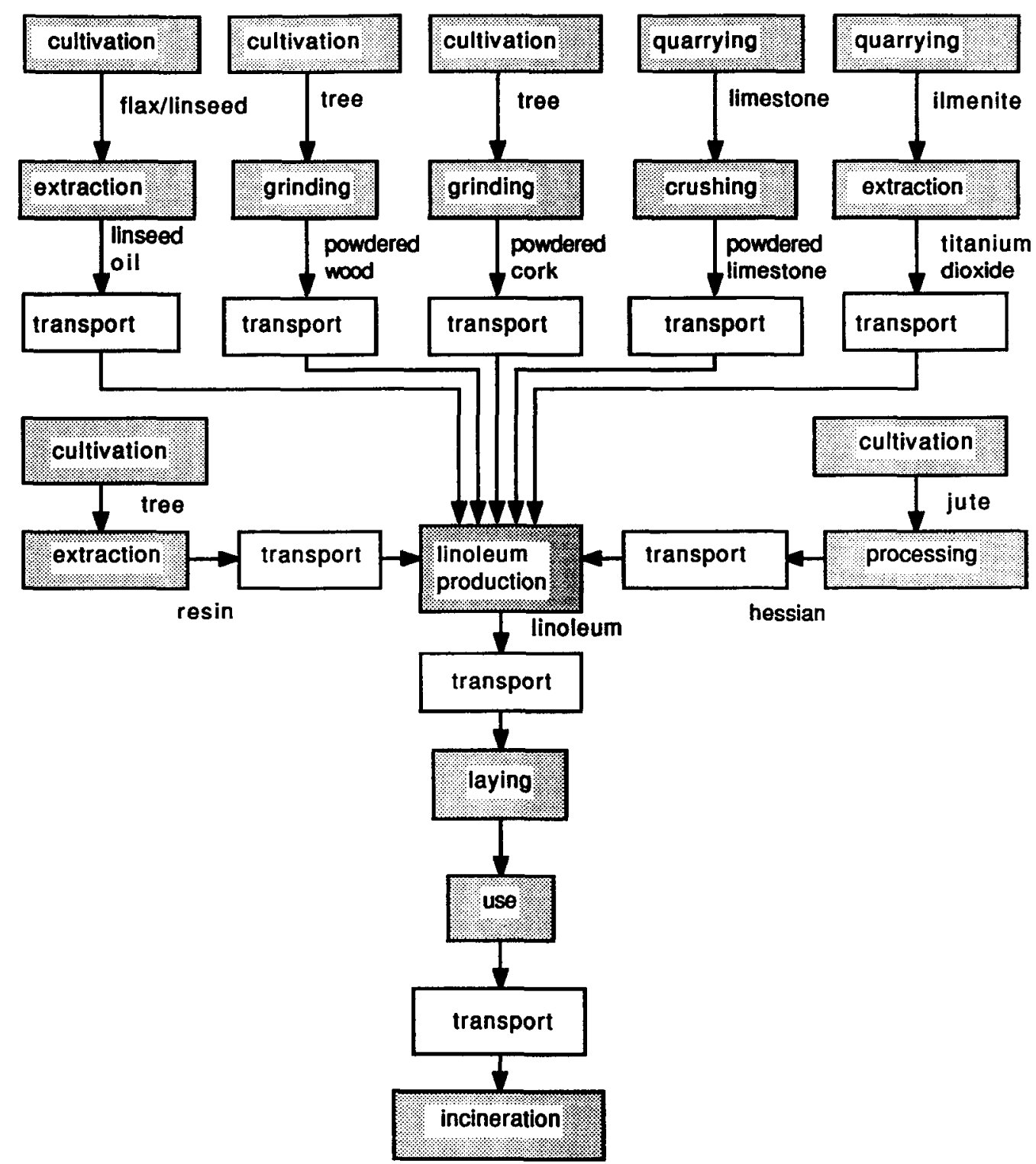

Fig. 1. Flow chart for linoleum. 


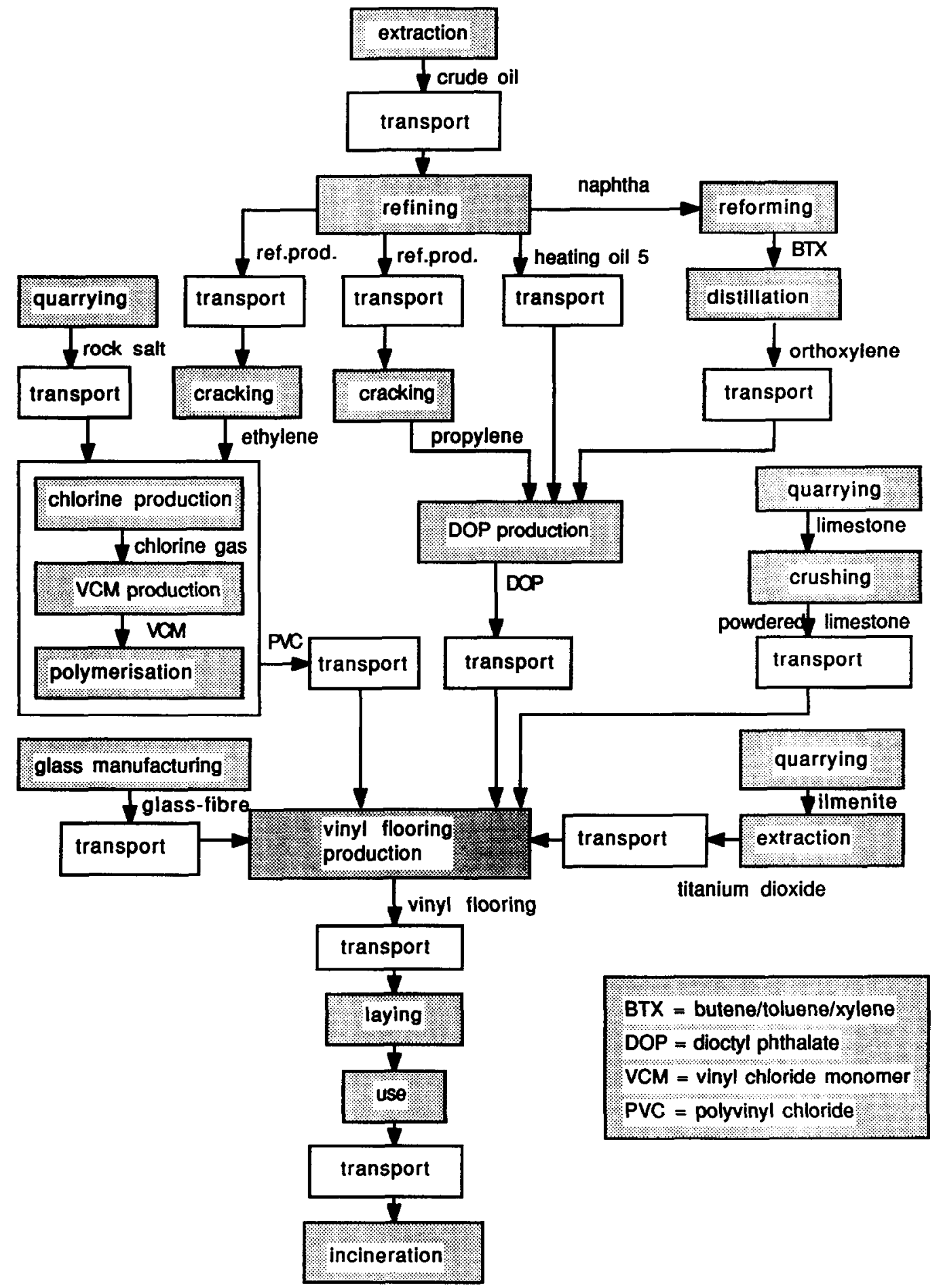

Fig. 2. Flow chart for vinyl flooring.

lubricants, foaming agents, stabilisers, flame-proofing agents, etc.) under heat and pressure, and the mixture is pressed onto a backing of fibreglass fabric. The plasticiser mainly used in the product studied is dioctyl phthalate (DOP). The plasticiser is an important additive which makes the PVC permanently more plastic and stretchable. The pigment mainly used is titanium dioxide. Calcium carbonate is the main filler used in the product studied. Finally, a surface layer of polyurethane (PUR) is put on.

\section{The life cycle of solid wood flooring}

Wood is the only raw material in wood flooring. A production cycle for forestry means that the forest has to be planted, grow, be thinned, be felled, soil-cultivated and re-planted. After cutting, the trees are transported 


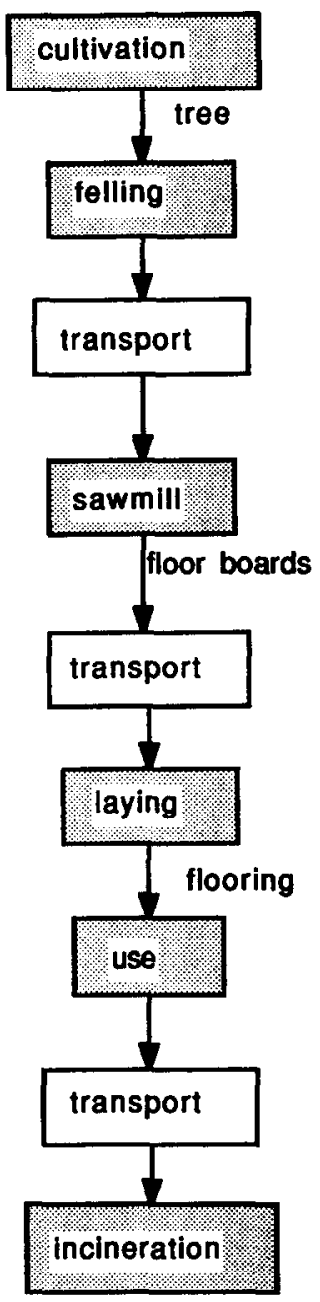

Fig. 3. Flow chart for solid wood flooring.

to sawmills, where barking, sawing to the desired dimensions and drying take place. The flooring is then transported to the customer, and laid.

\section{Inventory results}

Since the same parameters do not occur for all three floorings, it was difficult to compare the inventory results between them. To simplify comparison, the number of parameters was decreased by adding parameters considered to be of similar character, and then presenting the results split into four categories: resource use, energy use, emissions to air and water, and waste generation. Not all parameters were included.

Figure 4 shows that the vinyl flooring consumes the most non-renewable natural resources, whilst the wood flooring consumes by far the most renewable resources. A resource is referred to here as a technical resource when it has not been possible to trace the use of resources all the way back to the natural system. The production of renewable resources most often requires arable land, which means that the production of vinyl flooring requires less land than flooring made from renewable resources.

The bars for recovered energy and calorific value in Fig. 5 correspond to one another apart from in the efficiency of the recovered energy, as the calorific value is regained in incineration. The wood flooring shows the lowest total energy requirement, provided the flooring materials are incinerated with energy recovery.

Some emissions to air are shown in Fig. 6. Vinyl flooring showed the highest emissions for three of the five parameters, but the difference between the different flooring materials is not sufficiently clear for any definite ranking to be made. The wood flooring has consistently relatively low emissions, apart from $\mathrm{NO}_{x}$.

For all waste parameters (c.f. Fig. 7), wood gives rise to the least waste, whilst vinyl flooring causes the most ash and sector-specific waste. Linoleum gives rise to the most hazardous waste. No definite conclusions can be drawn from Fig. 7 with regard to the ranking of linoleum and vinyl flooring.

The conclusion of the quantitative inventory results, is that the solid wood flooring has the lowest environmental load. The difference between linoleum and vinyl flooring is less clear, and depends on what environmental parameters are considered most important.

\section{Environmental toxins}

It is not always possible to quantify emissions of environmental toxins such as some chloro-organic compounds, but the occurrence of such substances in the life cycle of a product can be established. National and international lists of chemical products regarded as environmentally hazardous may then be used to assess toxicity risks, as a supplement to the quantitative analysis of the environmental load. In this study the "List of 40" [9] was used as a basis. This list constitutes a collection of examples of substances regarded by the Swedish National Chemicals Inspectorate as environmentally hazardous. Of these 40 substances, six occurred in the life cycle of vinyl flooring (hexachlorobutadiene, chlorinated paraffins, carbon tctrachloridc, copper and its compounds, mercury and its compounds and 2,3,7,8-tetrachlorodibenzodioxin and other PCDDs and PCDFs), while none of them was identified in the life cycles of wood or linoleum. This is not surprising, since many of the substances on the list are chloro-organic compounds. According to the assessment based on the "List of 40", the vinyl flooring may be regarded as the worst choice from the environmental point of view.

\section{IMPACT ASSESSMENT}

The inventory results were evaluated by using three quantitative impact assessment methods, as follows.

1. The Environmental Priority Strategies in product design (EPS) method, developed in Sweden [10]. This evaluation is based on willingness within the OECD countries to restore to a reference condition the five safeguarded objectives: biological diversity, human health, production, aesthetic values and natural resources.

2. The Environmental Theme method, developed in the Netherlands [11]. Inventory data are converted to contributions to environmental problems, known as environmental themes. The model has been adapted to Swedish conditions [12], and the environmental themes have been weighed against one another on the 
Table 2. Total environmental load of $1 \mathrm{~m}^{2}$ linoleum ( $2.556 \mathrm{~kg}$, including laying waste)

\begin{tabular}{|c|c|c|}
\hline Parameter & Amount & Dominant activity \\
\hline \multicolumn{3}{|l|}{ Use of resources } \\
\hline titanium dioxide ${ }^{\dagger}$ & $102 \mathrm{~g}$ & linoleum production (raw material) \\
\hline limestone & $460 \mathrm{~g}$ & linoleum production (raw material) \\
\hline resin & $204 \mathrm{~g}$ & linoleum production (raw material) \\
\hline wood ${ }^{*}$ & $767 \mathrm{~g}$ & linoleum production (raw material) \\
\hline cork & $128 \mathrm{~g}$ & linoleum production (raw material) \\
\hline hessian & $280 \mathrm{~g}$ & linoleum production (raw material) \\
\hline linseed ${ }^{\ddagger}$ & $588 \mathrm{~g}$ & linoleum production (raw material) \\
\hline $\mathrm{K}_{2} \mathrm{O}$ & $13.5 \mathrm{~g}$ & flax cultivation (fertiliser) \\
\hline $\mathrm{P}_{2} \mathrm{O}_{5}$ & $16.5 \mathrm{~g}$ & flax cultivation (fertiliser) \\
\hline forest land $d^{\ddagger}$ & $4.52 \mathrm{~m}^{2}$, year & tree cultivation \\
\hline arable land $\mathrm{d}^{\ddagger}$ & $9.82 \mathrm{~m}^{2}$, year & flax cultivation \\
\hline \multicolumn{3}{|l|}{ Use of energy } \\
\hline electricity & $16.3 \mathrm{MJ}$ & $\begin{array}{l}\text { linoleum production ( } 44 \% \text { ) } \\
\text { titanium dioxide production }(30 \%)\end{array}$ \\
\hline fossil fuels & $25 \mathrm{MJ}$ & linoleum production $(67 \%)$ \\
\hline calorific value & $45.2 \mathrm{MJ}$ & calorific value of flooring material \\
\hline recovered encrgy & $-28.8 \mathrm{M}$ & incineration \\
\hline \multicolumn{3}{|l|}{ Emissions to air } \\
\hline $\mathrm{CO}_{2}$ & $1.6 \mathrm{~kg}$ & linoleum production $(58 \%)$ \\
\hline $\mathrm{CO}^{-}$ & $1.06 \mathrm{~g}$ & transports $(80 \%)$ \\
\hline $\mathrm{SO}_{2}$ & $4.3 \mathrm{~g}$ & transports $(62 \%)$ \\
\hline \multirow[t]{3}{*}{$\mathrm{NO}_{x}$} & $12.8 \mathrm{~g}$ & incineration $(40 \%)$ \\
\hline & & transports $(31 \%)$ \\
\hline & & linoleum production $(20 \%)$ \\
\hline VOC & $5.87 \mathrm{mg}$ & linoleum production $(87 \%)$ \\
\hline solvents & $3.12 \mathrm{~g}$ & linoleum production \\
\hline terpenes & $34.5 \mathrm{mg}$ & powdered wood production \\
\hline dust & $34.5 \mathrm{~g}$ & powdered limestone production $(96 \%)$ \\
\hline \multicolumn{3}{|l|}{ Emissions to water ${ }^{8}$} \\
\hline & $2.38 \mathrm{mg}$ & transports $(65 \%)$ \\
\hline phenol & $0.034 \mathrm{mg}$ & transports $(65 \%)$ \\
\hline COD & $6.96 \mathrm{mg}$ & transports $(65 \%)$ \\
\hline tot-N & $1.14 \mathrm{mg}$ & transports $(65 \%)$ \\
\hline \multicolumn{3}{|l|}{ Waste } \\
\hline ash & $555 \mathrm{~g}$ & incineration \\
\hline sector-specific waste & $17.2 \mathrm{~g}$ & hessian production \\
\hline hazardous waste & $238 \mathrm{~g}$ & titanium dioxide production \\
\hline
\end{tabular}

* Only accounted for as resource use (no other envirunmental loads are included).

†According to one titanium dioxide producer, $6.25 \mathrm{~kg}$ ilmenite ore is required for production of $1 \mathrm{~kg}$ titanium dioxide).

$\ddagger$ Wood and linseed are included both as mass and as land use. This is in a sense double accounting, but for the impact assessment which follows it is beneficial that both parameters are presented.

$\S$ Emissions occurring at precombustion processes of fossil fuels (refining, etc.).

basis of Swedish environmental policy objectives for 1995.

3. The Ecological Scarcity method, developed in Switzerland [13]. Ecological scarcity is defined as the ratio between total environmental impact and critical impact within a geographically defined area. The critical impact is primarily calculated on the basis of ecological conditions, "what nature tolerates", secondly on the basis of political objectives. The model has been adapted to Swedish conditions [12].

The results of the impact assessment are presented in Table 5. Values are presented firstly for the total lifetime (total $/ \mathrm{m}^{2}$ ), then distributed per year on the lifetime of each flooring material (total/year, $\mathrm{m}^{2}$ ). As can be seen, all the methods identified the pine flooring as the most environmentally sound, whilst the ranking of linoleum and vinyl flooring varied. For the EPS method, use of fossil resources and emissions of carbon dioxide weighed heavily in the assessment. The quantity of hazardous waste was an important parameter in the assessment for the other two methods, especially for the Ecological Scarcity method. The main part of the hazardous waste stemmed from the production of titanium dioxide.

\section{VALIDITY OF RESULTS}

The effects of feasible changes in the life cycles of the products on the result of the inventory and impact assessment, and on the order in which the products are ranked, were analysed. The results of this variation analy. sis are described below.

As a result of the publication of the original Swedish report [1], some new data for the environmental load of titanium dioxide production were made available by the 
Table 3. Total environmental load of $1 \mathrm{~m}^{2}$ vinyl flooring ( $1.444 \mathrm{~kg}$, including laying waste)

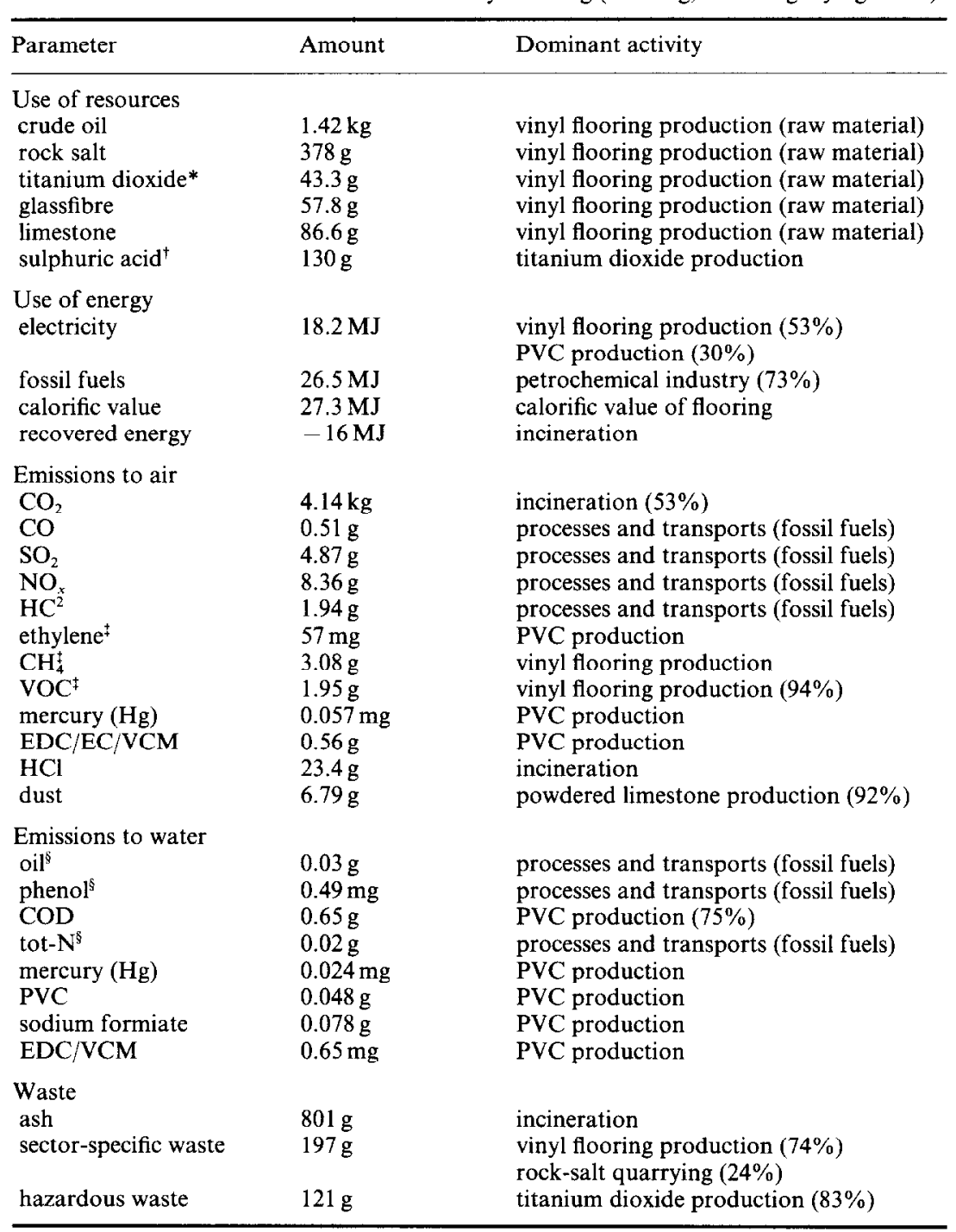

* $6.25 \mathrm{~kg}$ ilmenite ore is required for production of $1 \mathrm{~kg}$ titanium dioxide.

†Only accounted for as resource use (no other environmental loads are included).

\$The parameter names overlap in some respects, but are nevertheless separated in the table, owing to the form in which the data have been given in the inventory.

$\S$ Emissions occurring during precombustion processes of fossil fuels (refining, etc.).

titanium suppliers. These data were valid at the time of the inventory, although not known to the authors. When utilising these more recent data, the impact assessment values were reduced for both linolcum and vinyl flooring. (See Table 6.) The change was most important for linoleum, which has a higher content of titanium dioxide than vinyl flooring per square metre. When taking the lifetime into account, linoleum and solid wood flooring had similar impact values with the Environmental Theme method. As the EPS method does not have any ELU value for waste and hazardous waste, these figures remained unchanged regardless of whether or not hazardous waste was taken into account. Vinyl flooring got the highest environmental impact in all three methods, when the new data were used.

Especially for linoleum production, most of the raw materials were transported long distances. It was of interest to see whether the environmental performance was affected by diminishing the transport distances. There- fore, some raw materials (linseed oil, powdered wood, powdered limestone) were replaced in the calculations with raw materials of Swedish origin. This proved to have no significant effect on the total impact because of the relatively low impact levels for raw material production and transportation for both the old and new inventory data.

The load-bearing function was included in the functional unit by adding a bearing floor sheet (particle board) to the linoleum and vinyl flooring and increasing the thickness of the solid wood flooring. When the environmental consequences were analysed, the conclusion was strengthened that the solid wood flooring is the most environmentally sound product.

The environmental impact of cleaning and maintenance during the period of use probably accounts for an important part of the total environmental impact of the flooring material. However, this impact may be regarded as being of little significance to the results of 
Table 4. Total environmental load of $1 \mathrm{~m}^{2}$ solid wood flooring ( $7.4 \mathrm{~kg}$, including laying waste)

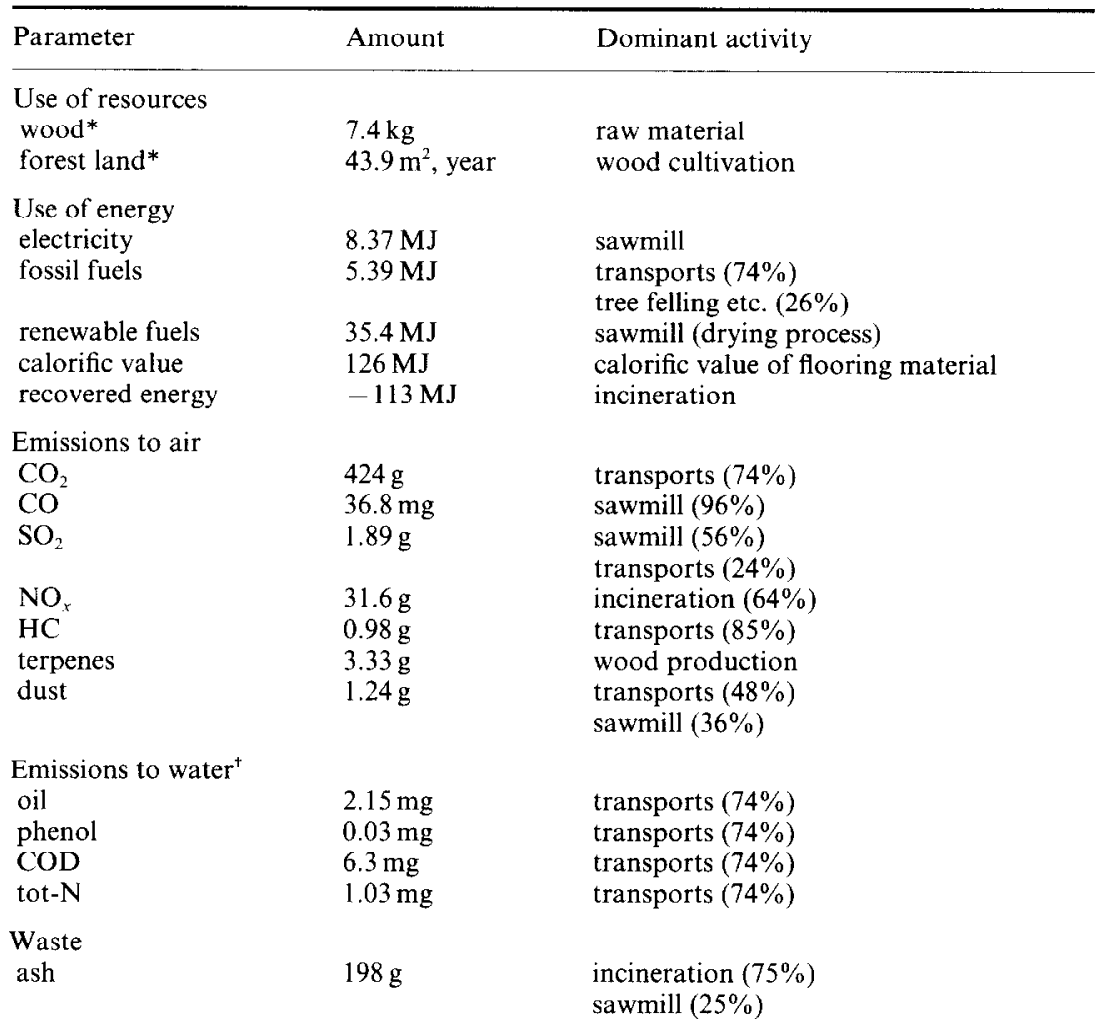

*Wood is included both as mass and as land. This is in a sense double accounting, but for the impact assessment which follows it is beneficial that both parameters are presented.

†Emissions occurring during preconbustion processes of fossil fuels (refining, elc.).

this report as the impacts in a comparative study cancel one another out, provided that the floorings are maintained in a similar way.

The three flooring types are all used also in public areas, although with a change in proportional composition and specific weight. In addition, the pine flooring is generally varnished. A rough estimate was made of the environmental performance of public-area floorings, based on the inventory results. Most parameters ranked the wood flooring as the most environmentally sound and vinyl flooring as the least environmentally sound product. The ranking order was more evident for public than for domestic floorings. However, the environmental impact of cleaning and maintenance may be supposed to

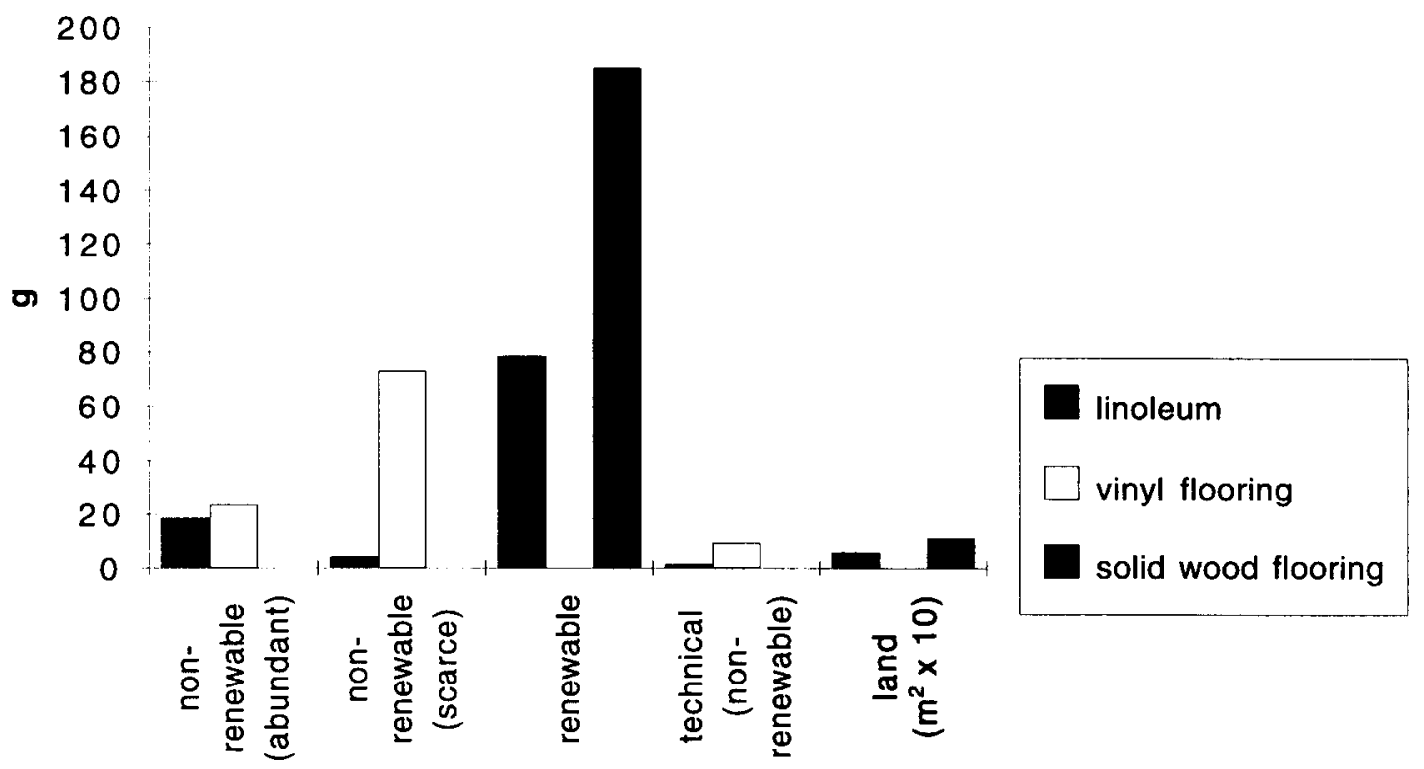

Fig. 4. Resource use per functional unit (year and $\mathrm{m}^{2}$ ) flooring material. 


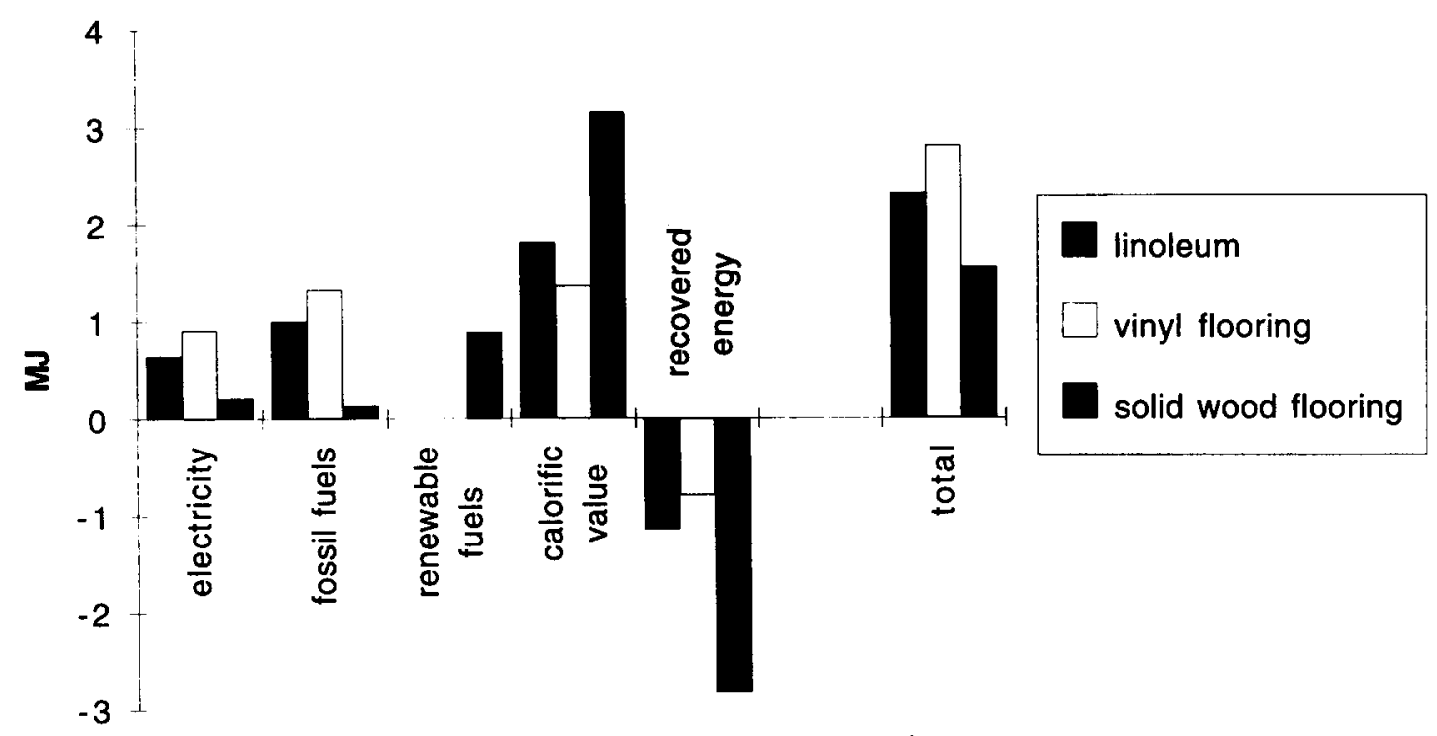

Fig. 5. Energy use per functional unit (year and $\mathrm{m}^{2}$ ) flooring material.

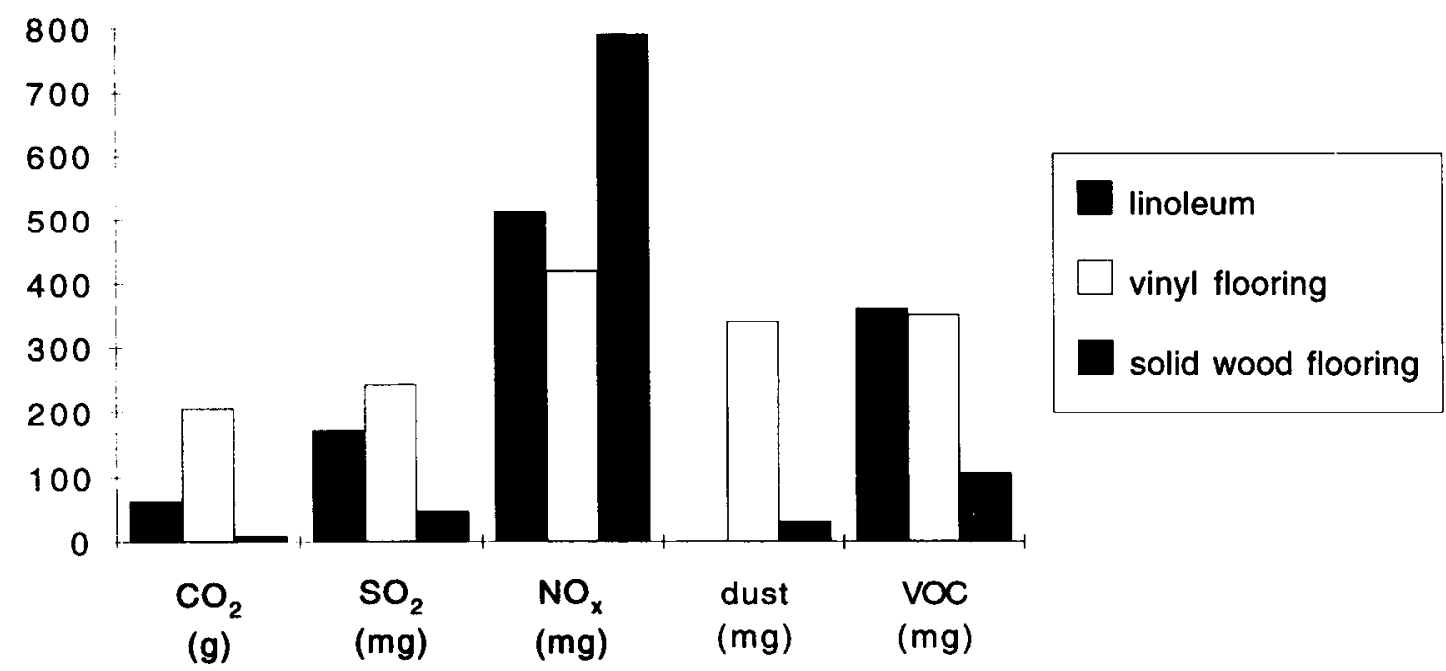

Fig. 6. Emissions to air per functional unit (year and $\mathrm{m}^{2}$ ) flooring material.

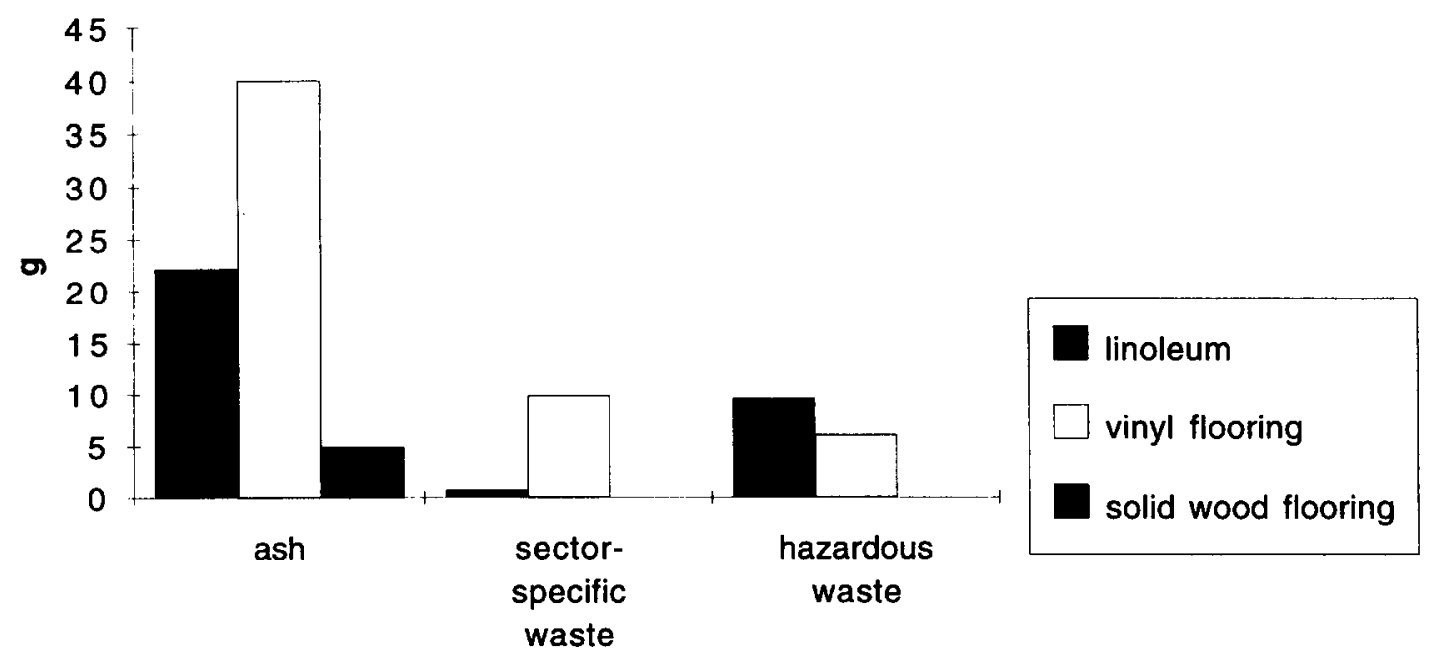

Fig. 7. Waste generation per functional unit (year and $\mathrm{m}^{2}$ ) flooring material. 
Table 5. Comparative environmental assessment of linoleum, vinyl flooring and solid wood flooring according to three assessment methods. The values are presented in relation to those for wood

\begin{tabular}{lccc}
\hline $\begin{array}{l}\text { Impact assessment method } \\
\text { Linoleum }\end{array}$ & $\begin{array}{c}\text { Vinyl } \\
\text { flooring }\end{array}$ & $\begin{array}{c}\text { Solid wood } \\
\text { flooring }\end{array}$ \\
$\begin{array}{l}\text { EPS method } \\
\text { total } / \mathrm{m}^{2} \\
\text { total/year, } \mathrm{m}^{2}\end{array}$ & 4.2 & 12.5 & 1 \\
$\begin{array}{l}\text { Environmental theme method } \\
\text { total } / \mathrm{m}^{2}\end{array}$ & 6.7 & 25 & 1 \\
$\begin{array}{l}\text { total } / \text { year, } \mathrm{m}^{2} \\
\text { tcological scarcity method } \\
\text { total } / \mathrm{m}^{2}\end{array}$ & 1.9 & 1.9 & 1 \\
total $/$ year, $\mathrm{m}^{2}$ & 3.1 & 3.8 & 1 \\
\hline
\end{tabular}

be even greater for public than for domestic floorings, which may influence the ranking order when taken into consideration. In addition, as public floorings are professionally cleaned and maintained, it can no longer be assumed that the cleaning habits are probably independent of what floor covering is used.

\section{DISCUSSION AND CONCLUSIONS}

The conclusion drawn from the findings of both the inventory and the impact assessment was that the solid wood flooring under the given conditions is clearly the most suitable alternative of the three materials studied, from the environmental point of view. Based solely on the quantitative inventory results, no definite conclusions could be drawn as to whether linoleum or vinyl flooring is preferable. When taking into account also the assessment of environmentally hazardous substances in the life cycles of the flooring materials and the findings of the impact assessment, it was concluded that linoleum is probably preferable to vinyl flooring from the environmental point of view.

There are gaps in data in the inventory documentation. The shortage of data is considered greatest for production of long distance raw materials for linoleum, such as resin, jute and cork. In the case of vinyl flooring, the environ-
Table 6. Comparative environmental assessments of linoleum vinyl flooring and solid wood flooring according to three assessment methods, provided no hazardous waste is gencrated in the production of titanium dioxide. The values are presented in relation to the flooring with the lowest value

\begin{tabular}{|c|c|c|c|}
\hline Impact assessment method & Linoleum & $\begin{array}{c}\text { Vinyl } \\
\text { flooring }\end{array}$ & $\begin{array}{l}\text { Solid wood } \\
\text { flooring }\end{array}$ \\
\hline \multicolumn{4}{|l|}{ EPS method } \\
\hline total/year, $\mathrm{m}^{2}$ & 6.7 & 25 & 1 \\
\hline Environmental theme method & $\mathrm{ad}$ & 2.2 & 1.7 \\
\hline total/year, $\mathrm{m}^{2}$ & 1 & 2.8 & 1.1 \\
\hline \multicolumn{4}{|l|}{ Ecological scarcity method } \\
\hline total/year, $\mathrm{m}^{2}$ & 1.6 & 8 & 1 \\
\hline
\end{tabular}

mental loads were omitted for a number of additives. It was considerably more difficult to obtain data for the processes which take place outside Sweden than for processes within Sweden.

When impact assessment methods are used, the result is partly governed by how a parameter is defined. The classes of impact categories are broad at present. Further development needs to be carried out, for example to produce effect weighting factors (indices) for more parameters. It is important that the results of the inventory are presented in connection with the impact assessment so that users themselves can examine what is decisive in the valuation method. Both the inventory and the impact assessment should be as "transparent" as possible, to assist a wide application of the result.

In further development of knowledge on the environmental impact of flooring materials, it is regarded very important to study the environmental impact of cleaning, care and maintenance during the period of use.

The lifetime of flooring materials affects their total environmental inpact. Whether or not a long lifetime is advantageous is partly governed by how cleaning and maintenance procedures change over the years. Another area considered important to study more closely is the long-term environmental effects of the landfilling of building waste.

\section{REFERENCES}

1. Jönsson, Å., Tillman, A-M. and Svensson, T., Livscykelanalys av golvmaterial (Life-Cycle Assessment of Flooring Materials). Report R30:1994, BFR (Swedish Council for Building Research), Stockholm, 1994 [in Swedish; an English translation will shortly be available from the Swedish Council for Building Research].

2. Potting, J. and Blok, K., De milieugerichte levensyklusanalyse van vier typen vloerbedekking (The Environmental Life Cycle Assessment of Four Types of Floor Covernng). P-UB-93-4, Coordination point science shops, Utrecht, 1993 [in Dutch].

3. Guidelines for Life-Cycle Assessment: A "Code of Practice". SETAC (Society of Environmental Toxicology and Chemistry), Brussels/Pensacola, 1993.

4. Tillman, A-M., Baumann, H., Eriksson, E. and Rydberg, T., Packaging and the Environment. SOU 1991:77, Gothenburg, 1991.

5. Information from GBR (Swedish National Flooring Trades Association), Stockholm, 1993.

6. Forbo-Krommenie, Krommenie, Netherlands, 1993-94.

7. Hydro Plast AB, Stenungsund, 1993-94

8. Tarkett AB, Ronneby, 1993-94.

9. Miljöfarliga ämnen - Exempellista och vetenskaplig dokumentation (Environmentally Hazardous Substances - Example List and Scientific Documentation). KemI (Swedish National Chemicals Inspectorate) Report 10/89, Stockholm, 1989 [in Swedish]. 
10. Steen, B. and Ryding, S-O., The EPS Enviro-Accounting Method. An Application of Environmental Accounting Principles for Evaluation and Valuation of Environmental Impact in Product Design. IVL report B 1080, IVL (Swedish Environmental Research Institute), Göteborg, 1992.

11. Heijungs, R., Guinée, J. G., Huppes, G., Lankreijer, R. M., Udo de Haes, H. A., Wegener Sleeswijk, A., Ansems, A. M. M., Eggels, P. G., van Duin, R, and De Goede, H. P., Environmental Life Cycle Assessment of Products-Backgrounds and Environmental Life Cycle Assessment of Products Guide. CML, TNO, B\&G, Leiden, 1992.

12. Miljömässiga skillnader mellan återvinning/återanvändning och förbränning/deponering (Environmental Differences Between Recovery/Reuse and Incineration/Land Filling). CTH, CIT, IVL, SI. Reforsk FoU no. 79, January 1993 [in Swedish].

13. Ahbe, S., Braunschweig, A. and Muller-Wenk, A., Methodik für Oekobilanzen auf der Basis ökologischer Optimierung (Methodology for Eco-balances Based on Ecological Optimisation). BUWAL Schriftenreihe Umwelt Nr 133, Bern, October 1990 [in German]. 